\title{
TANGGUNG JAWAB RUMAH SAKIT ATAS KELENGKAPAN INFORMED CONSENT PADA SAAT OPERASI DI RS PREMIER JATINEGARA JAKARTA
}

\author{
Sukendar, Agus H. Rahim dan Samuel Hutabarat \\ sukendarlaw@Yahoo.com \\ Magister Hukum Kesehatan \\ Universitas Katolik Soegijapranata Semarang
}

\begin{abstract}
ABSTRAK
Informed consent atau tindakan medis merupakan salah satu upaya pengembangan usaha kesehatan untuk meningkatkan pelayanan kesehatan pada masyarakat. Sebelum dilakukan tindakan pembedahan, dalam keadaan yang wajar memerlukan persetujuan dari pihak pasien.

Persetujuan ini dapat berupa persetujuan lisan atau persetujuan tertulis, hal ini tergantung dari besar dan kecilnya resiko dari pembedahan yang dilakukan. Hal seperti ini sudah diatur dalam perundang- undangan praktek kedokteran nomer 29 Tahun 2009 dan Undangundang Rumah Sakit nomor 44 tahun 2004 dan Undang-Undang Kesehatan Nomor 36 Tahun 2009 dan peraturan internal rumah sakit (Hospital by Laws).

Kesalahan dan kelalaian dalam melaksanakan profesi kedokteran merupakan masalah penting, karena dapat menyebakan kecacatan. Baik cacat sementara maupun cacat permanen, bahkan sampai menimbulkan kematian. Hal tersebut dapat merusak kepercayaan masyarakat terhadap profesi kesehatan .Sehingga pasien tidak melulu mengharapkan hasil yang baik dan sehingga setelah pembedahan tidak terjadi adanya konflik / kesalahpahaman yang akan menimbulkan adanya tuntutan.

Berdasarkan uraian tersebut, penulis tertarik untuk melakukan penelitian yang berjudul "TANGGUNG JAWAB RUMAH SAKIT ATAS KELENGKAPAN INFORMED CONSENT PADA SAAT OPERASI DI RS PREMIER JATINEGARA - JAKARTA".

Adapun perumusan masalah yang ada adalah bagaimana pengaturan tentang informed consent dikamar operasi sebelum melakukan tindakan pembedahan dilaksanakan di Rumah Sakit Premier Jatinegara, dan bagaimana dampak dan akidah hukum terhadap dokter atas kelengkapan informed consent di Rumah sakit Premier jatinegara.

Metode dalam penelitian ini adalah yuridis normatif. Pendekatan yuridis normatif ini dalam menganalisa dan meninjau masalah digunakan prinsip dan asas-asas hukum. Penelitian ini menentukan pada segi-segi yuridis dan melihat pada Perundang-undangan yang berkaitan dengan pelaksanaan pemberian tindaklan medis / informed consent.
\end{abstract}

Kata Kunci : Tanggung Jawab Rumah Sakit, Informed Consent Pada Saat Operasi 


\section{A. TANGGUNG JAWAB RUMAH SAKIT}

Terjadinya sengketa medik antara dokter dengan pasien atau pasien dengan rumah sakit biasanya karena dokter / rumah sakit kurang dapat menjalin hubungan komunikasi yang baik dengan pasien. Hal tersebut disebabkan karena beberapa hal yaitu, pejelasan tentang isi informasi dan alternatif pengobatan yang dipilih tidak disampaikan secara lengkap, kapan informasi itu disampaikan, cara penyampaian informasi, siapa yang berhak atas informasi, yang berhak memberikan informasi dan yang berhak atas informasi. Hubungan dokter dan pasien akan terjalin dengan baik apabila keduanya mengetahui fungsi masing-masing, dimana seorang dokter tidak hanya berperan menghadapi penyakit saja tapi harus berinteraksi sekaligus dengan penderita secara emosional. Dalam melakukan tugasnya dokter dan tenaga kesehatan harus mematuhi, Undang-Undang Nomor 29 Tahun 2004 Tentang Praktik Kedokteran (UUPK), Undang-Undang Nomor 36 Tahun 2009 Tentang Kesehatan (UUKes), Undang-Undang Nomor 44 Tahun 2009 Tentang Rumah Sakit (UURS), dan Peraturan Internal Rumah Sakit (hospital by laws). Kesalahan dan kelalaian dalam melaksanakan profesi kedokteran merupakan masalah penting, karena dapat menyebabkan kecacatan. Baik cacat sementara maupun permanen, bahkan sampai dengan menimbulkan kematian. Hal tersebut dapat merusak kepercayaan masyarakat terhadap profesi kesehatan.

Dalam kontek penelitian ini penulis ingin lebih fokus meneliti di bagian kamar operasi agar dapat memonitor secara langsung dalam pelaksanaan tindakan operasi karena operasi adalah risiko yang paling tinggi dalam tindakan pembedahan sehingga setiap dokter bedah, perawat dan petugas administrasi lainnya lebih peduli/awere dalam cek dan ricek kepada pasien sebelum operasi dilakukan. Terkadang terjadi dokter bedah ketika memdapat konsul dari teman sejawatnya suatu kasus bedah dan diyakini pula kasus bedah maka dokter bedah langsung instruksikan persiapan dan segera operasi (Cito). Dokter bedah langsung memberikan instruksi pasien diantar ke kamar operasi tanpa memberikan informed consent terlebi dahulu kepada pasien dan keluarga. Hal ini kerap terjadi hampir di seluruh belahan rumah sakit. Hal demikian kedepannya di rumah sakit premier jatinegara tidak akan terjadi lagi dan disarankan manajemen lebih giat lagi dalam mensosialisasikan aturan yang telah disahkan Undang-Undang Republik Indonesia ini.

Pandangan masyarakat awam khususnya dan masyarakat Indonesia pada umumnya, baik masyarakat yang berprofesi dibidang kesehatan maupun masyarakat yang berprofesi dibidang lain, bahwa kasus-kasus yang terjadi pada bidang kesehatan terutama dirumah sakit dalam hubungan antara dokter dan pasien selalu diselesaikan / dilaporkan melalui jalur kepolisian. Padahal kasus-kasus sengketa medik dirumah sakit diawali dengan pernyataan persetujuan pasien sebagaimana yang tertulis pada Peraturan Menteri Kesehatan Nomor 290/MENKES/PER/III/2008, Pasal 1 item 1, yaitu:

"Persetujuan tindakan kedokteran adalah persetujuan yang diberikan oleh pasien atau keluarga terdekat setelah mendapat penjelasan secara lengkap mengenai tindakan kedokteran atau kedokteran gigi yang akan dilakukan terhadap pasien"

Seiring perjalannya bukan berarti tidak membuat informed consent bisa dipidakan, tetapi pada kenyataannya bila terdapat suatu kasus yang istilah bahasa awamnya adanya dugaan kelalaian dalam melakukan tindakan pembedahan perlu seblumnya diinformasikan terlebih dahulu kepada pasien dan keluargannya tetapi bila belum dikomuniasikan dan timbul hasil tidak diharapkan oleh pasien dan keluarga maka hal persetujuan dan penjelasan ini dapat titik awal dari adanya perselisihan. Betul memang bukan berarti tidak membuat informed consent dapat dipidana, tetapi dari hasil kajian audit medik internal komite medik rumah sakit bahwa dokter yang tidak melakukan dan atau tidak membuat informed consent akan bisa dikenai sangsi administrasi berupa teguran dan bisa juga disampaikan ke MKDKI kalau hal ini sudah terpublikasi keluar. 
Di Rumah sakit Premier jatinegara membuat pengolahan data dari para dokter bedah yang setiap harinya melakukan tindakan pembedahan dengan memeriksa informed consent yang komplit, informed consent yang parsial / separoh /tidak komplit dan tidak membuat informed consent.

Penyelesaian sengketa medik yang terjadi dapat diselesaikan diluar pengadilan yaitu dengan cara konsultasi, negosiasi, mediasi, konsiliasi dan penilaian ahli. Apabila sengketa tersebut menimbulkan suatu kerugian bagi pasien kemudian pasien menganggap hal tersebut dokter melakukan suatu kelalaian / kesalahan (tidak memenuhi prestasi), maka tidak harus melaporkan ke pihak yang berwajib (polisi). Sesuai dengan asas-asas perundangan-undangan yang mengatakan bahwa lex specialis derogat legi generalis (aturan yang khusus mengenyampingkan aturan yang umum). Undang-Undang Nomor 36 Tahun 2009 tentang Kesehatan, Pasal 29;

"Dalam hal tenaga kesehatan diduga melakukan kelalaian dalam menjalankan profesinya, kelalaian tersebut harus diselesaikan terlebih dahulu melalui mediasi”.

Terdapat 900 kasus dalam penelitian 3 bulan yang penulis lakukan dari bulan desember 2012 sampai bulan pebruari 2013. Dari 900 kasus operasi penulis melakukan sample secara random tiap bulan mengambil 100 kasus dan di jumlah selama 3 bulan adalah 300 sample. Ada 1 kasus dokter yang tidak membuat informed consent pada sample bulan januari dalam tindakan debridement + advanement Flep. Dan selebihnya dokter patuh menjalankan SOP RS Premier jatinegara bahwa sebelum melakukan tindakan perlu adanya informed consent. Bukti bahwa para tenaga kesehatan baik dokter bedah dan lainnya dapat melakukan dan menjalankan SOP ini dengan baik dan benar sesuai dengan semboyan RS Premier Jatinegara Caring people for caring.

\section{B. KELENGKAPAN INFORMED CONSENT PADA SAAT AKAN TINDAKAN PEMBEDAHAN}

Pada umumnya setiap rumah sakit mempunyai peraturan internal Rumah Sakit (Hospital Bylaws) ini bertujuan untuk mengatur batas kewenangan, hak, kewajiban dan tanggung jawab pemilik, Direktur rumah sakit selaku pengelola, dan staf medis yang terhimpun dalam komite medis sehingga setiap persoalan antar mereka lebih mudah diselesaikan akibat adanya hubungan yang selaras dan serasi. Rumah Sakit sebagai sarana perlindungan hukum memberikan kewenangan klinis (Clinical Privilage) adalah hak klinis yang diberikan kepada staf medis untuk melakukan pelayanan medis dan tindakan medis pada pasien dirumah sakit.

Kewenangan klinis diberikan oleh Direktur rumah sakit atas rekomendasi dari komite medis dalam bentuk surat penugasan (Clinical Appointment). Anggota staf medis mempunyai hak untuk melakukan pelayanan medis kepada pasien, termasuk pemeriksaan, pengobatan dan tindakan medis lainnya yang dipandang perlu. Setiap staf medis dalam melakukan pelayanan medis harus sesuai dengan kualifikasi dan kompetensi individu yang dimilikinya. Maka dari itu bagi para dokter bedah di rumah sakit premier jatinegara yang akan melakukan tindakan pembedahan perlu adanya surat persetujuan atau informed consent agar supaya segala tindakan terlindungi oleh hukum.

Peraturan ini berlaku bagi para dokter bedah dan atau dokter bedah gigi dan mulut, baik itu dokter purnawaktu, dokter paruh waktu dan dokter Tamu sekalipun, dan terikat dengan perjanjian kerja masing-masing kualifikasi dokter tersebut. Undang-undang praktek kedokteran sudah melindungi setiap warga negaranya dalam segala tindakan. Namun terkadang dalam aplikasi dilapangan masih segelintir warganya tidak peduli untuk mentaati peraturan tersebut dan terkadang para dokter sadar bilamana nanti tersangkut konflik medis bahkan sampai timbul sengketa medis. 
Dalam rangka peningkatan mutu profesi medis dan mutu pelayanan medis dan demi terciptanya koordinasi, intergrasi dan sinkronisasi pelayanan di rumah sakit maka perlu ada penyusunan kebijakan pelayanan medis sebagai standar yang harus dilaksanakan oleh semua kelompok staf medis di Rumah Sakit. Apabila dalam pelaksanaan keseharian kedapatan para dokter ahli bedah dalam tindakannya tidak membuat informed consent maka bisa dikenai sangsi administrasi dan berlanjut ke badan Majelis kedispilinan kedokteran Indonesia (MKDKI).

\section{PERUMUSAN MASALAH}

Berdasarkan latar belakang yang telah penulis paparkan diatas maka dapat ditarik dan diambil masalah yang ada adalah sebagai berikut:

a. Bagaimana tanggung jaab rumah sakit tentang informed consent dikamar operasi sebelum tindakan pembedahan dilaksanakan dirumah sakit premier jatinegara?

b. Bagaimana akibat hukum terhadap dokter yang tidak lengkap membuat informed consent di RS Premier Jatinegara?

\section{TUJUAN PENELITIAN}

Adapun tujuan penelitian ini adalah :

a. Untuk memberikan gambaran tentang tanggung jawab rumah sakit atas Kelengkapan informed consent yang berdasarkan KUHP pasal 351 dan Permenkes Nomor 290/Menkes/PER/III/2008.

b. Memberikan perlindungan kepada pasien atau pihak tertentu terhadap tindakan dokter yang sebenarnya tidak diperlukan dan secara medik tidak ada dasar pembenaran yang dilakukan tanpa sepengetahuan pasiennya.

c. Memberi perlindungan hukum kepada dokter terhadap suatu kegagalan dan bersifat negatif, karena prosedur medik modern bukan tanpa resiko.

\section{E. HASIL REKAPITULASI PENCATATAN INFORMED CONSENT}

Penelitian dilakukan dikamar operasi Rumah Sakit Premier jatinegara yang dalam perbulannya jumlah operasi biasanya berjumlah 300-350 jenis operasi. Yang dapat penulis lakukan terhitung bulan desember 2011,januari 2012, dan februari 2012. Adapun populasi yang diambil hanya berjumlah 100 jenis operasi saja dengan kategori untuk dalam pengamatan seputar pengisian informed consent komplit, tidak komplit / parsial dan atau tidak membuat sama sekali.dengan melakukan random dari sample tersebut dapat penulis simpulkan bahwa hasil tersebut masih kurang dari harapan peraturan pemerintah tentang wajibnya membuat informed concent.

Hasil Rekapitulasi informed Consent pasien operasi di RS Premier Jatinegara pada bulan desember 2012 sampai dengan bulan pebruari 2013.

Data Informed Consent pada Rekam Medik

Periode Desember 2012

\begin{tabular}{|c|c|c|}
\hline Lengkap & Tidak Lengkap & Tidak Ada \\
\hline 89 & 11 & 0 \\
\hline $89 \%$ & $11 \%$ & $0 \%$ \\
\hline
\end{tabular}

Sample tiap bulan yang di ukur adalah 100 BRM dari jumlah BRM 300 yang di ukur 
Data Informed Consent pada Rekam Medik

Periode Januari 2013

\begin{tabular}{|c|c|c|}
\hline Lengkap & Tidak Lengkap & Tidak Ada \\
\hline 86 & 13 & 1 \\
\hline $86 \%$ & $13 \%$ & $1 \%$ \\
\hline
\end{tabular}

Sample tiap bulan yang di ukur adalah 100 BRM dari jumlah BRM 300 yang di ukur

Data Informed Consent pada Rekam Medik

Periode Februari 2013

\begin{tabular}{|c|c|c|}
\hline Lengkap & Tidak Lengkap & Tidak Ada \\
\hline 81 & 19 & 0 \\
\hline $81 \%$ & $19 \%$ & $0 \%$ \\
\hline
\end{tabular}

Sample tiap bulan yang di ukur adalah 100 BRM dari jumlah BRM 300 yang di ukur

Data Informed Consent pada Rekam Medik

Periode Desember 2012 s/d Februari 2013

\begin{tabular}{|c|c|c|}
\hline Lengkap & Tidak Lengkap & Tidak Ada \\
\hline $85 \%$ & $14 \%$ & $1 \%$ \\
\hline
\end{tabular}

Kesimpulan dari hasil penelitian selama 3 bulan ( desember 2012 - februari 2013)

\section{F. HUBUNGAN PERSETUJUAN TINDAKAN MEDIS DAN PERLINDUNGAN HUKUM BAGI DOKTER}

Hubungan dokter dan pasien adalah hubungan yang bersifat kontraktual yang menghasilkan adanya suatu kesepakatan atau perikatan kedua belah pihak (verbintenis), dari perikatan itulah kemudia muncul antara hak dan kewajiban dari masing-masing pihak, dimana hak dan kewajiban tersebut merupakan hubungan yang diatur oleh hukum.

Akibat adanya ketidakpahaman mengenai hak dan kewajiban menyebabkan adanya kecenderungan untuk mengabaikan hak-hak pasien, sehingga perlindungan bagi pasien semakin bias. Ada yang menilai kedudukan pasien lebih rendah dari dokter, sehingga dokter dianggap dapat mengambil keputusan sendiri terhadap pesien mengenai tindakan yang akan dilakukannya. Bila dilihat dari perjajian terapeutik, pendapat diatas keliru karena dengan adanya perjanjian terapeutik kedudukan dokter dan pasien adalah sama atau sederajat.

Dokter yang memberikan pelayanan medis wajib memberikan prestasinya, sedangkan pasien wajib memberikan kontra-prestasi. Bentuk prestasi tergantung dari jenis perikatan yang disepakati, yaitu perikatan ikhtiar (inspaning-verbintenis) atau perikatan hasil (resultaatverbintenis). Jenis perikatan antar dokter dan pasien yang lazim, yaitu perikatan ikhtiar dimana dokter hanya dituntut untuk memberikan prestasinya berupa upaya medis yang layak berdasarkan teori kedokteran yang sudah di uji kebenarannya dan sesuai dengan prosedur yang sudah ditetapkan. 
Objek perikatan yang merupakan hak dan kewajiban dokter disebut prestasi, menurut pasal 1234 KUHPerdata : "Tiap-tiap perikatan adalah untuk memberikan sesuatu, untuk berbuat sesuatu, atau untuk berbuat sesuatu". Perkataan sesuatu tersebut dapat berbentuk materiil (berwujud) dan imateriil (tidak berwujud). Prestasi dalam memenuhi perikatan harus memenuhi syarat-syarat sebagai berikut :

a. harus diperkenankan, artinya tidak boleh bertenangan dengan Undang-Undang, ketertiban umum dan kesusilaan (pasal 1335 dan 1337 KUHPerdata)

b. Harus tertentu atau dapat ditentukan, artinya harus terang dan jelas (pasal 1320 ayat (3) dan Pasal 1333 KUHPerdata),

c. Harus mungkin dilakukan, artinya mungkin dilaksanakan menurut kempuan manusia"

Sumber perikatan yang terpeting adalah perjanjian sebab melalui perjanjian pihakpihak mempunyai kebebasan untuk membuat segaa macam perikatan, sesuai dengan azas kebebasan berkontrak yang terkadung didalam KUHPerdata.

Syarat-syarat untuk sahnya suatu perjanjian tercantum dalam pasal 1320 KHUPerdata, yaitu :

a. Sepakat mereka yang mengingatkan dirinya

b. Cakap untuk membuat suatu perjanjian

c. Suatu hal tertentu dan

d. Suatu sebab yang halal

Prestasi adalah sesuatu yang wajib dipenuhi oleh dokter dalam setiap perikatan. Sedangkan wanprestasi adalah seuatu keadaan dimana seseorang tidak memenuhi kewajibannya yang didasarkan pada suatu perjanjian. Seseorang yang dapat dianggap melakukan wanprestasi apabila :

a. Tidak melakukan yang disanggupi akan dilakukan

b. Terlambat melakukan apa yang dijanjikan akan dilakukan

c. Melaksanakan apa yang dijanjikan, tetapi tidak sesuai dengan yang dijanjikan, dan

d. Melakukan sesuatu yang menurut perjanjian tidak boleh dilakukannya

Menurut PERMENKES R.I No. 290/MENKES/PER/III/2008, istilah Informed Consent ini diterjemahkan dengan persetujuan tindakan medis. Sejak berlakunya PERMENKES tersebut, jika seorang dokter bedah, isalnya hendak melakukan operasi, maka terlebih dahulu ia harus memberikan penjelasan mengenai tindakan yanga akan dilakukan, apa risikonya, manfaatnya, ada tidaknya alternatif lain, apa yang mungkin terjadi apabila pembedahan itu tidak dilakukan. Keterangan ini harus diberikan secara jelas dalam bahasa sederhana yang dapt dimengerti oleh pasiennya, dengan memperhitungkan tingkat pendidikan dan intelektualnya. Jika pasien suda mengerti sepenuhnya dan memberikan persetujuan tindakan medis barulah dokter bedah boleh melakukan tindakan operasi.

Peryataan tanda setuju secara tertulis hanya sebagai penegasan. Dengan adanya perstujuan tindakan medis dapat memudahkan pembuktian jika diperlukan kelak. Dilihat dari segi yuridis, dengan adanya tanda tangan pada formulir persetujuan tindakan medis, akan tetapi pasien menyangkal telah memberikan izinnya, maka pasienlah yang arus membuktikan ketidakbenaran apa yang telah disepakati. Namun jika hanya ditandatangani saja oleh pasien tanpa diberikan informasi yang jelas terlebih dahulu oleh dokter, maka secarik kertas yang ditandatangani itu secara yuridis tidak dapat menjadi bukti yang kuat secara hukum bagi 
dokter. Karena pasien dianggap belum informed, sehingga belum ada persetujuan tindakan medis dari pasien sebagaimana diatur dalam PERMENKES R.I No.290/MENKES/PER/III/2008.

Apabila sudah ada penjelasn dari dokter, dengan perkataan lain sudah ada persetujuan tindakan medis dari pasien, teryata dokternya melakuakn kelalaian (negligence). Apakah dokter tersebut tidak bisa dituntut karena sudah ada persetujuan tindakan medis dan tanda tangan pasien? Dokter tetap bisa dituntut, karena pasien hanya memberikan persetujuan tindakan medis untuk dilakkan tindakan medis tertentu. Dokter harus melakukan tidakan medis tersebut sesuai dengan standar profesi medis yang berlaku. Hal ini berarti bahwa dokter harus bekerja dengan hati-hati, teliti dan wajar, sesuai dengan apa yang lazim dilakukan dan akan dilakukan juga oleh dokter lain yang setingkat dan dalam keadaan yang sama.

Secarik kertas yang telh ditandatangani pasien tidak membebaskan dokter dari tuntutan atas kelalaian yang dilakukannya. Secara yuridis, seseorang termasuk dokter tidak dapat sebelumnya membebaskan diri terhadap tuntutan karena kelalaian. Hal ini bertentangan dengan KUHPerdata pasal 1373 jo. Pasal 1375 tentang "suatu sebab perikatan yang tidak di izinkan".

Dalam praktik sehari-hari, perumusan semacam ini (pro-forma consent) dipergunakan oleh beberapa dokter. Mungkin mereka beranggapan bahwa dengan perumusan itu mereka sudah dapat membebaskan dirinya dari tanggung jawab dan tuntutan hukum jika kelak terjadi sesuatu yang tidak diinginkan.

Lain halnya jika pada suatu operasi timbul komplikasi yang tidak diduga sebelumnya dan terjadi di luar kesalahan/kelalaian dokter, dalam hal ini dokter tidak dapat dipersalahkan karena pada setiap tindakan medis apalagi tindakan operasi selalu melekat dengan risiko, inilah yang dinamakan inherent risk. Risiko yang terjadi diluar kealahan/kelalaian dokter adalah menjadi tanggung jawab pasien. Misalnya, sewaktu pasien diberi narkose oleh dokter ahli anastesi timbul syok anafilaktik, yaitu suatu reaksi berlebihan dari badan pasien itu sendiri. Hal semacam ini tidak dapat diperhitungkan oleh dokter (unexpected risks) sehingga dokter tidak dapat dipersalahkan.

Biasanya, satu hari sebelum operasi, dokter ahli anestesi harus datang memeriksa pasien untuk menanyakan apakah ia sudah pernah dioperasi, riwayat alergi obat, tekanan dara tinggi, penyakit diabetes, perokok berat, alkoholik dan sebagainya, sebagai upaya persiapan untuk tindakan pencegahan bila terjadi diluar dugaan.

Bagaimana dengan tindakan medis non bedah? Apakah perlu persetujuan tindakan medis dari pasien? Didalam peraturan tersebut dikatakan bahwa selain tindakan bedah, juga tindakan invasif atau tindakan lain yang mengandung risiko tinggi harus diberikan penjelasan terlebih dahulu. Misalnya: pemeriksaan radiologi dengan kontras, penyinaran dengan X-ray, kateterisasi jantung dan sebagainya.

Informasi harus diberikan dengan itikad baik, secara jujur dan tidak bersifat menakutnakuti atau memberi atau memberi tekanan/pemaksaan. Pemberian informa harus dilakukan oleh dokter itu sendiri dan tidak boleh didieligasikan kepada perawat karena hal iniakan membahayakan bagi dokter itu sendiri dan tanggung jawab tetap pada dokternya. Informasi ini harus diberikan kepada pasien baik diminta atau tidak diminta kecuali pasien itu sendiri menolak untuk diberi penjelasan. Maka informasi dapat diberikan kepada salah satu anggota keluarga terdekat. Dokter tidak boleh menahan-nahan informasi kecuali jika ia berpendapat bahwa informasi itu bila diberikan langsung kepada pasien akan memperburuk kesehatan pasien. 
Persetujuan tindakan medis adalah :

a. Hubungan dokter pasien yanga berdasarkan atas kepercayaan

b. Hak otonomi atau menentukan atas dirinya sendiri

c. Adanya hubungan penjanjian antara dokter dan pasien

Tujuan dari persetujan tindakan medis adalah :

a. Melindungi pasien terhadap segala tindakn medis yang dilakukan tanpa epengetahuan pasien. Misalnya jika ada penyalahgunaan pemkaian alat-alat canggih yang memerlukan biaya tinggi. Hal ini memeang sulit dikontrol, karena sebagai profesi dokter ia berhak melakukan tindakan yang dianggap perlu. Namun, pengunaan peraltan cangih pada satu pihak dapat memberi perlindungan kepada dokter apabila timbul suatu tuntutan, ia bisa dianggap lalai, bila tidak menyuruh pasien melakukan pemeriksaan tertentu sehingga menimbulkan suatu hasil negatif (adverse outcome).

b. Memberikan perlindungan hukum kepada dokter terhadap akibat yang tidakterduga/bersifat negatif, misalnya risks of treatment yang tidak mungkin duindarkan meskioun dokter sudah berusaha maksimal mungkin dan bertindak hati-hati dan teliti. Misalnya ditemukan perlengketan-perlengketan yang berbahaya pada pembedahan. Adanya istilah error of jugement, dokter juga manusia biasa dan iapun tidak terindar dari kesalahan/kekeliruan. Bisa saja diagnosa yang ditegakkan atau terapi yang diberikan itu keliru, namun dalam batas-batas tertentu sepanjang ia bekerja secara lege artis maka dokter tidak dapat dipersalahkan. Lain halnya bila ia melakkan suatu kesalahan besar karena kelalaian (negligence) yang sebenarnya oleh teman sejawat lainnya tidak akan dilakukan. Hal ini juga bisaterjadi karena unsur ketidktahuan (ignorance) terhadap ilmu medis yang berkembeng pesat. Jika suatu al diketahui secara umum oleh seyiap dokter lain dan merupakan standar medis, maka ia tetap dapat dipersalahkan.

Menurut KODEKI pasal 18 dikatakan bahwa "Setiap dokter hendaklah senantiasa mengikuti perkemangan ilmu pengetahuan dan tetap setia kepada cita-cita yang luhur".

Sebagai seorang dokter ia diwajibkan untuk megikuti perkembangan ilmu pengetahuan di bidang medisnya.

Bagaimanakah pelaksanaan persetujuan tindakan medis di dalam praktiknya sekarang? Dengan berlaknya PERMENKES R.I Nomor 290/MENKES/PER/III/2008 tentanga peretujuan tindakan medis tersebut, maka hal ini sudah merupakan kewajiban hukum bagi para dokter. Jika timbul suatu tuntutan dimana pihak dokter tidak memberikan informasi terlebih dahulu kepada pasiennya, maka kedududkan dokter secara hukum lemah.

Bagaimana jika pasien dalam keadaan emergensi? Apakah persetujuan tindakan medis masih tetap perlu? Persetujuan tindakan medis tetap penting. Tetapi bukan prioritas karena prioritas pertama adalah menyelamatkan jiwa. Oleh karena itu pelaksanaan peretujuan tindakan medis pada keadaan emergensi tidak boleh menjadi penghambat atau penghalang dilakkannya emergency care, PERMENKES R.I No. 290/MENKES/PER/III/2008 menyatakan bahwa dalam keadaan emergensi tidak diperlukan persetujuan tindakan medis. Berbagi yurisprudensi di negara-negara maju menunjukan kesamaan prinsip, bahwa tindakan emergency care dapat dilakukan tanpa perstujuan tindakan medis.

Demikian pula apabila informasi yang diberikan kurang jelas, sehingga pasien tidak mengerti atau salah paham mengenai tindakan yang akan dilakukan dokternya, bisa timbul masalah hukum karena bisa ditafsirkan adanya unsur kekhilafan (dwaling). Menurut hukum suatu persetujuan yang diberikan atas dasar kekhilafan tidak mempunyai kekuatan hukum (KUHPerdata pasal 1321). 
Persetujuan yang diberikan dengan tidak didahului informasi atau didahului informasi tetap tidak cukup, maka peretujuan tersebut dianggap tidak perrnah ada (tidak sah demi hukum). Informasi urus diberikan sejelas-jelasnya, tetapi jika pada akhirnya pasien menolak memberikan peretujuannya berarti dokter tela gagal dalam melakukan komunikasi.

Dengan demikian apabila dokter telah melaksanakan persetujuan tindakan medis/ Informed Consent dalam kontrak terapeutik antara dokter dan pasien, maka persetujuan tindakan medis tersebut dapat melindung dokter tersebut dari kemungkinan tuntutan hukum.

Dalam rangka mewujudkan hal tersebut, rumah sakit memerlukan suatu peraturan internal rumah sakit (Hospital Bylaws) yang mengatur antara pemilik atau yang mewakili dengan pengelola rumah sakit yang disebut peraturan internal korporasi (Corporate Bylaws) serta peraturan yang mengatur hubungan, hak dan kewajiban dari Direktur Rumah Sakit dan Staf medis yang disebut peraturan internal staf medis (Medical Staff Bylaws) dalam bentuk aturan tertulis tertinggi yang berlaku secara khusus di Rumah Sakit Premier jatinegara yang sekaligus untuk dijadikan acuan dalam penyusunan berbagai aturan pelaksanaan'1.

Bahwa sebagai pelaksanaan pasal 45 Undang-Undang Nomor 29 Tahun 2004 tentang praktek kedokteran, perlu mengatur kembali Persetujuan Tindakan Medik dengan peraturan Menteri Kesehatan; Undang-Undang Nomor 23 Tahun 1992 tentang Kesehatan (lembar Negara Republik Indonesia Nomor 3495);..........jo Undang-Undang Kesehatan nomor 36 Tahun 2004 . Undang-Undang Nomor 29 Tahun 2004 tentang praktek kedokteran (lembar Negara Republik Indonesia Tahun 2004 Nomor 116, tambahan lembaran Negara Republik Indonesia Nomor 4431); Peraturan Pemerintah Nomor 10 Tahun 1966 tentang Wajib Simpan rahasia Kedokteran (Lembaran Negara Republik Indonesia Nopmor 2803); Peraturan pemerintah Nomor 32 Tahun 1996 tentang Tenaga Kesehatan (Lembar Negara Tahun 1996 Nomor 39 Tambahan lembar negara Nomor 3637); Peraturan Menteri Kesehatan Nomor 920/ Menkes/ Per/ XII/ 1986 tentang Upaya Pelayanan Kesehatan Swasta di Bidang medik; Peraturan Menteri kesehatan Nomor 159b/ Menkes/Per/II/1988 tentang Rumah sakit sebagaimana telah diubah terakhir dengan keputusan menteri kesehatan dan Kesejahteraan Sosial Nomor 191/Menkes-Kesos/SK/II/2001 tentang perubahan keputusan Menteri Kesehatan Nomor 157/Menkes/SK/III/1999 tentang perubahan kedua atas peraturan Menteri Kesehatan Nomor 159b/Menkes/Per/II/1988 tentang Rumah Sakit; Peraturan Menteri kesehatan Nomor 1575 /Menkes/Per/XI/2005 tentang Organisasi dan Tata Kerja Departemen kesehatan sebagaimana telah diubah dengan peraturan menteri kesehatan Nomor 1295/Menkes/per/XII/2007 tentang perubahan pertama atas peraturan Menteri Kesehatan Nomor 1575/Menkes/Per/XII/2005 tentang Organisasi dan Tata kerja Departemen Kesehatan.

Dokter bedah di rumah sakit premier jatinegara menurut catatan kepegawaian terdiri dari dokter purna waktu, dokter paruh waktu, dan dokter tamu. Dalam pelaksanaan standar operating prosedur harus dapat melakukan dan melaksankan peraturan yang di adakan atau di sediakan oleh manajemen untuk di laksanakan. Sehingga dalam memberikan tindakan dalam pelayanan semua dapat terkendali dan dapat dipantau oleh manajemen rumah sakit. Sehingga masalah sekecil apapun akan dapat terselesaikan, jika semua para dokter itu peduli akan rambu-rambu yang telah di sepakati manajemn dan para dokter tersebut diatas. Doktrin di rumah sakit premier bahwa tindakan sekecil apapun harus membuat surat persetujuan tindak medic atau informed consent. Karena bila ada kesalahan yang dilakukan di dalam rumah sakit dianggap sebagai "Kelalaian institusi" (corporate negligence) yang harus ditanggung oleh konstitusinya karena dianggap kurang bias mengawasi dan mengontrol apa yang dilakukan anak buahnya, termasuk juga kelalaian yang dilakukan oleh para dokternya, baik dokter umum maupun dokter spesialis dan dokter kedokteran gigi. 
Berdasarkan doktrin ini rumah sakit sebagai suatu institusi yang menyediakan diri untuk menyediakan diri untuk memberikan pelayanan. Pengobatan dan perawatan (cure and care) juga bertanggung jawab atas segala peristiwa yang terjadi di rumah sakit. Tegasnya, yang pertama-tama bertanggungjawab adalah rumah sakitnya, namun bila ada kesalahan / kelalaian yang tidak wajar, bias saja pimpinan rumah sakit kemudian menggunakan hak regresnya (minta digantikan lagi) kepada dokter yang telah berlaku lalai. Sekarang sudah lazim keduannya dituntut sekaligus, karena dianggap sebagai "deep pocket" yang finansialnya lebih kuat.

Namun rumah sakit untuk mengurangi resiko kerugiannya bias saja sebelumnya membuat perjanjian pribadi terlebih dahulu antara Rumah sakit dan dokter sebagai syarat untuk boleh menjalankan praktek dirumah sakit itu dan untuk membagi tanggungjawabnya. Caranya antara mana bina sebahagian dari honornya harus disetorkan kepada rumah sakit untuk in case ada tuntutan bias digunakan untuk membayar kerugian tersebut. Jadi semacam "fonds risiko".

Kitab Undang-Undang Hukum Pidana (KUHP), a. Kejahatan Terhadap Pemalsuan, Pasal 267 KUHPidana : "Seorang dokter yang dengan sengaja member surat keterangan palsu tentang ada atau tidaknya penyakit, kelemahan atau cacat, diancam dengan Pidana penjara paling lama empat tahun".

Pasal 267 KUHP di atas memang pasal khusus yang hanya dikenakan bagi dokter. Maksudnya yaitu hanya orang tertentu yang mempunyai sifat atau kualitas pribadi sebagai dokter saja yang dapat dijadikan subjek hukum yang melakukan kejahatan pemalsuan ini. Agar rumusan pasal 267 ini bias dikenakan kepada dokter, unsure sengaja harus terpenuhi, karena bisa terjadi dokter salah dalam menentukan diagnose, sehingga salah pula dalam menerbitkan surat yang dibuatnya. Saran penulis terhadap pasal ini sebaiknya dimasukin juga unsure kelalaian yang dilakukan oleh dokter.

Undang-Undang Nomor 36 Tahun 2009 Tentang kesehatan, yang berkaitan dengan kelalaian, Pasal 29 Undang-Undang Nomer 36 tahun 2009, yaitu "dalam hal tenaga kesehatan diduga melakukan kelalaian dalam menjalankan profesinya, kalalaian tersebut harus diselesaikan terlebih dahulu melalui Mediasi".

\section{G. KESIMPULAN}

Persetujuan Tindakan Medis / informed consent bisa diberikan secara tertulis (untuk tindakan berisiko tinggi / invasive) maupun secara lisan, diberikan setelah pasien mendapat informasi yang adekuat.

Dari hasil penelitian tersebut diatas berarti Rumah Sakit Premier jatinegara mendekati yang diharapkan amanat undang-undang dalam pelaksanaan pengisian informed Consent kepada pasien sebelum dilakukan tindakan pembedahan. Informed consent di setiap rumah sakit berbeda-beda namun tetap sumbernya satu yaitu dari Peraturan Pemerintah tentang informed consent. dari hasil penelitian bahwa nilai $85 \%$ adalah dokter membuat informed consent secara lengkap sebelum dilakukan pembedahan dan adapun 14\% dokter bedah ada kekurang lengkapan dalam pengisian informed consent dan sedangkan sisanya $1 \%$ dokter ada yang tidak membuat informed Consent karena faktor lupa dan merasa sudah mendelegasikan ke petugas kesehatan lainnya. Hal ini harus lebih diingatkan kembali arti pentingnya akan pengisisan informed consent ini. Yang dituntut oleh undang-undang baha keberhasilan harus mencapai $100 \%$ berarti semua dokter harus ajib dan tunduk kepada aturan yang telah berlaku. dokter bedah juga diharpakan patuh dan taat terhadap standar operating prosedur yang di terapkan di Rumah Sakit Premier jatinegara.

2 J. Guwandi, SH. Hukum Rumah sakit \& Corporate Liability, Fakultas kedokteran UI. hal 1 
Segala tindakan kedokteran apapun tindakanannya harus diutamakan membuat suatu pernyataan atau informed consent kepada pasien dan keluargannya. Adapun tindakan kedokteran harus di jelaskan kepada pasien manakala pasien itu sudah berumur diatas 21 tahun dan atau yang sudah menikah.

Hubungan dokter dan pasien dalam aspek hukum kesehatan, terjalin dalam suatu ikatan terapeutik / kontrak terapeutik, dokter dan pasien mempunyai hak dan kewajiban yang sama-sama harus di hormati.

Dokter tidak berhak melakukan tindakan medis yang bertentangan dengan keamanan pasien meskipun untuk kepentingan pasien, maka sebelum dilakukan tindakan dokter harus mendapatkan persetujuan tindakan medis terlebih dahulu dari pasien dan atau keluargannya.

Latar belakang perlunya persetujuan tindakan medis/ informed consent, karena :

a. Tindakan medis penuh ketidakpastian (Uncertainty) dan hasilnya tidak dapat diperhitungkan secara matematik,

b. Hampir semua tindakan medis memiliki resiko,

c. Tindakan medis tertentu memiliki akibat efek samping yang tidak menyenangkan pasien,

d. Semua resiko jika benar terjadi atau semua akibat efek samping yang tidak menyenangkan akan dirasakan sendiri oleh pasien,

e. Resiko maupun akibat efek samping tersebut biasanya sulit di pulihkan kembali,

f. Munculnya pola hidup konsumerisme.

Dahulu hubungan dokter dan pasien bersifat paternalistik, pasien selalu mengikuti petunjuk dokter tanpa di beri kesempatan untuk bertanya tentang penyakitnya dan jenis tindakan yang akan dilakukan. Namun zaman era globalisasi ini berbeda karena semua pelanggan rumah sakit sudah mulai pinter dan dapat memberikan masukan yang membangun untuk para dokter. Zaman sudah berubah dengan semakin pesatnya pertumbuhan dan tekhnologi yang semakin hari semakin tajam.

Dilihat dari segi yuridis, Persetujuan Tindakan medis / informed consent menunjukan kepada aturan hukum yang menentukan kewajiban dokter dalam berhubungan dengan pasien. Di lihat dari segi etika, persetujuan tindak medis / informed consent adalah pencetusan nilai-nilai otonomi dalam masyarakat yang diyakini sebagai hak mereka untuk menentukan nasibnya sendiri.

Persetujuan tindakan medis / informed consent adalah persetujuan yang diberikan oleh pasien / keluarganya atas dasar penjelasan mengenai tindakan medis yang akan dilakukan terhadap pasien tersebut. Maksudnya untuk memberikan perlindungan yang seimbang dan objektif baik terhadap dokter maupun pasien. 


\section{DAFTAR PUSTAKA}

Achidiat M. Chrisdiono, 1996, Pernik-Pernik Hukum kedokteran, Jakarta, Widya medika

Anny Isfandyarie, 2006, Tanggung jawab Hukum dan Sanksi Bagi Dokter, buku I, Prestasi Pustaka, Jakarta.

Azwar, Azrul, 1990, Aspek etik persetujuan tindakan medik, Lokakarya Izin tindakan medik, Jakarta.

Azwar, Azrul, 1996, Pengantar Administrasi Kesehatan, (Jakarta : Binarupa Aksara

Ari Yunanto, dr. Sp.A, SH, 2009, Hukum Pidana Malpraktek Medik Tinjauan dan Perspektif Medikolegal, Penerbit Andi.

Bahder J Nasution, SH, M.Hum, 2005, Hukum Kesehatan, Penerbit Rhineka Cipta

Departemen Kesehatan RI, 1983, Kode Etik Kedokteran Indonesia, DEPKES RI, Jakarta:.

Djaja S. Meliala, SH. MH, 2008, Perjanjian Pemberian Kuasa Menurut Kitap Undang-undang Hukum Perdata.

dr. Hj. Anny Isfandyarie, Sp.An., SH, Tanggung Jawab Hukum dan Sanksi bagi Dokter Buku 1, Prestasi Pustaka Publisher.

Dr. Veronica Komalawati, 1999, Peranan Informed Consent dalam Transaksi Teraupetik, Bandung: PT. Citra Aditnya Bhakti.

Endang Wahyati Yustina, 2012, Mengenal Hukum Perumahsakitan, CV Keni Media, Bandung.

F. Ameln, 1991, Kapita Selekta Hukum Kedokteran, Grafikatama Jaya, Jakarta.

J. Guwandi, SH, 2011, Hukum Rumah Sakit \& Corporate Liability, FKUI.

R. Soesilo, 1996, Kitab Undang-undang Hukum Pidana (KUHP), Politea, Bogor.

Soerjono Soekanto, 1989, Aspek Hukum Kesehatan (Suatu Kumpulan Catatan), Jakarta : IND-HILLCO.

Sofwan Dahlan, 2000 Hukum Kesehatan, Rambu-Rambu Bagi Profesi Dokter, Semarang, Badan Penerbit UNDIP.

Titik Triwulan Tutik, SH.,MH \& Shita Febriana, S.Ked, 2010, Perlindungan Hukum Bagi Pasien, Prestasi Pustaka Publisher, Jakarta.

Achmad Biben, 2005, Alternatif : Bentuk Informed Consent dalam praktek dan penelitian kedokteran, bandung, FKUI.

Anny Isfandyarie, 2006, Tanggung jawab Hukum dan sangsi bagi dokter, Prestasi Pustaka, Jakarta.

Bahder J. Nasution, 2005, Hukum Kesehatan : Pertanggungjawaban Dokter, Rineka Cipta, Jakarta.

C.S.T. Kansil, 2002, Pengantar Ilmu Hukum dan Tata Hukum Indonesia, Jakarta Balai Pustaka.

Fred Ameln, 1991, Kapita Selekta Hukum kedokteran, Grafikatama jaya, Jakarta.

Hermien H. Koeswadji, 1998, Hukum Kedokteran : Studi Tentang Hubungan Hukum Dalam mana Dokter sebagai salah satu pihak, Citra Aditya Bakti, bandung. 